\title{
Paradiplomacy, Security Policies and City Networks: the Case of the Mercocities Citizen Security Thematic Unit
}

\author{
Gilberto Marcos Antonio Rodrigues* \\ Thiago Mattioli*
}

\begin{abstract}
In a phenomenon known as paradiplomacy, cities are playing an increasingly important role in international relations. Through paradiplomacy, cities are co-operating internationally with other cities, and city networks have become important spaces for sharing experiences of and best practices in local public policy. Moreover, security policy is a increasingly important part of local policy-making. In Latin America, the concept of citizen security, based on a democratic and human rights approach, has developed in response to the legacy of authoritarian regimes from the 1960 s to the 1980s. This article examines how security policies have been disseminated, discussed and transferred through Mercocities, the main city network in South America.
\end{abstract}

Keywords: Paradiplomacy; International Decentralised Co-operation; Mercocities; Security Policies; Citizen Security; Policy Transfer; Policy Diffusion.

\section{Introduction}

Paradiplomacy is an increasingly important dimension of contemporary International Relations (IR). In fact, the international relations of non-central governments challenge the traditional Westphalian IR paradigm in which national states are the only relevant actors (Tavares 2016; Kuznetsov 2015; Michelmann 2009; Vigevani et al 2004; Aldecoa and Keating 1999).

Non-central governments, also known as subnational governments, include the governments of states, provinces, cantons, länder or regions in federal states or decentralised states, all with a certain degree of administrative and political autonomy. In turn, these

\footnotetext{
* Federal University of ABC, São Paulo-SP, Brazil; gilberto.rodrigues@ufabc.edu.br. ORCID iD 0000-00015150-5146.

** Federal University of ABC, São Paulo-SP, Brazil; thiago.mattioli@ufabc.edu.br. ORCID iD 0000-00025648-6359.
} 
units encompass cities, which also tend to have high levels of political and administrative autonomy in democratic states (Anderson 2008).

Cities have significantly increased their participation in international affairs. This is so for various reasons, among them the need to improve their policies by learning from international examples and best practice, as well as the internationalisation of local public policy agendas by the UN system as well as regional organisations (Castells and Borja 1996; Borja and Castells 1997).

City networks are particularly relevant as a kind of collective paradiplomacy, with a major impact on policies on the environment, sustainable development, and many other local and regional issues (Happaerts, Van den Brande and Bruyninckx 2011; Rodrigues et al 2009). In this setting, with international co-operation as the keystone, internationalists and policy-makers are faced with an important research problem: could local public policies be transferred internationally through horizontal co-operation?

Public policy transfers (Dolowitz and Marsh 2000; Gilardi 2012) have featured prominently on the agenda of intergovernmental organisations such as the World Bank and UN Development Programme (UNDP), but also within regional regimes such as the EU, the Organization of American States (OAS), and Mercosur.

One of the most important public policies adopted by the state, security policy, is not traditionally part of local competence, because these are constitutional measures reserved for national and/or regional/state jurisdictions. Nevertheless, there has been a worldwide trend towards the 'localisation' of security policies in which cities have played a bigger role, both nationally and internationally. A good example of this is the Global Network on Safer Cities (GNSC), launched by UN-Habitat in 2012, which focuses on exchanging experiences on urban safety.

How cities worldwide have been influenced by others in respect of security policies is a matter of innovative problematisation and advanced research. In Latin America, for instance, the Mercocities network has a thematic unit for 'citizen security', a concept that has been adopted and developed by the OAS.

This article analyses how city networks, taking Mercocities as a case study, have played a role in promoting local security policies under the 'citizen security' concept, and how that movement has influenced the spread of good practice in local security policies through partnerships and shared experiences in international city networks.

\section{Cities and paradiplomacy}

Cities are the oldest political entities in history, and played an important political role until the Middle Ages, when the advent of the nation-state in the 1500 s reduced them to relatively insignificant political players. However, the growth of globalisation in the 1990s and the rapid growth of urban areas worldwide, demanding solutions for environmental degradation, public transport, housing, education, health, and public services, have once again brought cities to the political forefront.

The huge growth of urban populations changed the priorities of policy-makers in the second half of the 20th century. The establishment, in 1977, of the UN Commission on 
Human Settlements (Habitat), which became UN Habitat in 2001, marked the growing importance of cities in international relations. The emergence of the global city (Sassen 2001) transformed some urban areas into major actors in international relations, because they could influence and control important trade, transport, capital, and migration flows connected with the world system.

One of the challenges surrounding large cities is to determine the public policies that metropolitan regions should provide their citizens. Security policy provides policy-makers at all levels of government with one of their most important challenges. The new city's role is not confined to national borders; instead, cities also play a new international role. This phenomenon was firstly observed by Duchacek $(1986,1990)$ and Soldatos (1990) in their research on federalism and federal states in the 1980s.

In the course of studies of the international role of subnational units, numerous new terms and concepts have been adopted, such as microdiplomacy, protodiplomacy, paradiplomacy (Duchacek 1986, 1990; Soldatos 1990), multilevel diplomacy (Hocking 1993, 2004), federative diplomacy, and federative foreign policy (Rodrigues 2008). However, the term 'paradiplomacy' has prevailed internationally as a way of describing the international actions of subnational units (Aguirre 1999; Kuznetsov 2015; Tavares, 2016).

In this sense, it is possible to describe paradiplomacy, following Cornago's masterful definition (1999: 40), as '... non-central governments' involvement in international relations through the establishment of permanent or ad hoc contacts with foreign public or private entities, with the aim to promote socioeconomic or cultural issues, as well as any other foreign dimension of their constitutional competences'.

Thus, paradiplomacy encompasses all kinds of non-central governments, from federal states and provinces, such as California in the USA, Ontario in Canada, Sao Paulo in Brazil and Bavaria in Germany, to relatively small cities and towns. But what are the factors that justify strategies of paradiplomacy? According to Andre Lecours (2008), the main factors that prompt cities to start practising paradiplomacy are economic, political, and co-operative. Of those, the need to co-operate in numerous policy areas, from the environment to education, has been most prominent. Through co-operation, city paradiplomacy deals with local security policy.

The growing importance of paradiplomacy for city policy-making has prompted many cities to create bureaucracies for dealing with this dimension, and contract skilled personnel. The institutionalisation of paradiplomacy and the international strategies adopted by local governments have become very sophisticated, especially in global and megacities such as Toronto and São Paulo (Vital 2016).

\section{Citizen security through paradiplomacy}

The concept of security, particularly in IR, is widely understood as the ability of the state to defend its territory against external threats, or the maintenance of world security, as in the case of the nuclear question - but always with a state-centred approach (UNDP 1994; UNTFHS 2009). After the Cold War, in the late 1980s, the concept evolved to include variables other than those in the classic realist approach, such as military threats. In fact, 
this happened in the course of the UN reform debate in the first years of the 1990s, which led to the UNDP proposing the concept of 'human security'.

Human security can be understood as a broader conception of security, with a focus on people rather than the nation-state. In this view, a broader range of threats can be identified, such as poverty, climate change, and human rights violations, with every threat pointing to a different type of security, including economic security, environmental security, political security, food security, and others (UNDP 1994; UNTFHS 2009).

Human security is a people-centred approach in which individuals become the main subject; it is multisectoral and comprehensive, understanding that those threats cannot be prevented or solved with stand-alone solutions; it is context-specific, considering that different localities and populations face different threats; and finally, it is oriented for prevention, meaning that prevention is much more cost-effective, and easier to implement (UNDP 1994; UNTFHS 2009).

Since 1994, the concept of human security has increasingly been adopted by different countries and international organisations as well as regional ones, and has shifted the traditional view of security in the international arena. The concept has also brought political and academic discussions about its definition and scope to international relations policy and theory. This has led to the formulation of two different notions of human security - a broad and a narrow one ${ }^{1}$ (Newman 2010; Fukuda-Parr and Messineo 2012).

The broader formulation is closely linked to the UNDP approach, and has been adopted by scholars with a more comprehensive view of the matter. This formulation derives, although not exclusively, from human rights theories and practices, taking into account the importance of freedom as a value and a key source of human choices. This broader formulation understands human security as a paradigmatic or foundational concept.

By contrast, the narrow definition focuses on immediate threats and acts of violence, particularly those that are politically organised and with political intent, such as genocide, crimes against humanity, and war crimes. Scholars who favour this narrow formulation understand human security as a policy tool, criticizing the broader formulation for its lack of precision, its inability to understand the reasons behind the threats, and its possible perverse effects, such as the misplaced use of force to solve political, economic or social problems (Newman 2010; Fukuda-Parr and Messineo 2012).

In Latin America and the Caribbean, authoritarian regimes, mainly from the 1960s to the 1980s, spawned gross violations of human rights and mass atrocities against civilians, committed by civil and military state security forces. Thus, since the democratic transitions beginning in the 1980s, the concept of state security has been questioned as an inappropriate approach to the protection of citizens (IACHR 2009). Influenced by the concept of human security as adopted by the UNDP (UNDP 1994; UNTFHS 2009), a new notion of security has evolved in Latin America and the Caribbean, aimed at overturning the legacy of institutional violence by security forces under the authoritarian regimes.

This has resulted in the notion of citizen security, a concept that still has no precise definition. However, it can be described as encompassing the exercise of human freedom and fundamental human rights, with capable institutions for maintaining and protecting those rights. In this sense, the citizen security approach can be seen as an essential 
expression of the concept of human security (UNDP 1994), and falling under the 'broad' formulation referred to earlier. In fact, the Inter-American Human Rights Commission (IAHRC) has stated that '[...] the concept of citizen security is the one that best lends itself to addressing the problems of crime and violence from a human rights perspective' (IAHRC 2009).

Implementing a new concept of security in a broad human rights perspective, which means placing the citizen instead of the state at the centre of security public policy, is a central government and/or state/provincial obligation. Generally, local governments do not adopt municipal security policies, since this is usually not part of their legal mandate, and has traditionally belonged to the central and state/provincial domain. Historically, this is true in almost all democratic federations and decentralised regimes.

Nevertheless, growing violence related to poverty, organised crime, drug trafficking, and gang activities is a growing obstacle to development, with high costs for national and local governments in Latin America in particular (IDB 2017), requiring an efficient and timely response from state/provincial as well as central governments. In many cases, this impact has been aggravated by the legacy of violent security forces under Latin America's authoritarian regimes. This has prompted city mayors to adopt new measures and new solutions for dealing with violence, and protecting their populations.

Similar security problems in cities has led to growing horizontal exchanges in regional and international fora. In the case of South America, the Mercocities network - the most important city network in the region - has played a central role in this respect. ${ }^{2}$ Since 2004, citizen security has become a major concern, leading to the establishment of the Citizen Security Thematic Unit (Unidade Temática Segurança Cidadã, or UTSC).

\section{Policy transfer and policy diffusion}

In order to analyse the UTSC's activities, we adopted a policy transfer/diffusion approach. The related literature has been developed since the 1960s through academic research in different areas of study, such as comparative politics, American politics, and international relations (Gilardi 2012; Graham, Shipan and Volden 2012).

Scholars have recently showed a growing interest in policy transfer/diffusion in Brazil. According to Faria, Côelho and Silva (2016), the CAPES/Thesis Database ${ }^{3}$ and the Scielo Platform list relatively few studies in this respect. However, the authors point to growing interest in this subject reflected in the agendas of research associations such as ANPOCS ${ }^{4}$ and the $\mathrm{ABCP}^{5}$ (Faria, Côelho and Silva 2016), with CEBRAP hosting an international conference on the subject ${ }^{6}$ in 2016 (CEBRAP 2016).

There are also papers, dissertations and theses dealing with these themes in the Brazilian academic literature, linked to IR studies, and featuring authors such as Marin (2011), Oliveira (2013), Mello (2013), Milani and Lopes (2014), and Rodrigues and Mattioli (2016). These studies examine how public policies are transferred or diffused, and which actors and mechanisms are involved in the process.

Policy transfer/diffusion studies have coined different concepts to illustrate this process. Analysts use no fewer than 104 different terms, which could be grouped into a few 
different mechanisms or processes (Graham, Shipan and Volden 2012). However, is essential to define policy transfer and policy diffusion before explaining these mechanisms, the actors involved, and what is transferred in the process in question.

Policy transfer may be defined as the 'process in which knowledge about policies, administrative arrangements, institutions and ideas in one political setting (past or present) is used in the development of policies, administrative arrangements, institutions and ideas in another political setting' (Dolowitz and Marsh 2000: 5). Policy diffusion takes place 'when one government's decision about whether to adopt a policy innovation is influenced by the choices made by other governments' (Graham, Shipan and Volden 2012: 3). Marsh and Sharman (2010) note that there are discussions about whether policy transfer and diffusion are part of the same process. The authors regard those concepts as overlapping and complementary, a position adopted in this article.

As regards the actors involved in policy transfer and diffusion, it is possible to identify three different kinds of actors, and ten specific actors. The kinds of actors are internal actors, who make decisions about public policy; external actors, namely the external governments that generate the polices which are adopted or transferred; and the go-betweens, non-government actors that are not involved in the policy process, but participate in policy discussions (Graham, Shipan and Volden 2012).

Specific actors are: 1) elected politicians and officials; 2) political parties; 3 ) bureaucrats and public servants; 4) advocacy groups; 5) experts and political entrepreneurs; 6) transnational corporations; 7) think-tanks; 8) international and supranational organisations; 9) non-governmental organisations; and 10) consultants (Dolowitz and Marsh 2000).

Many of those actors, particularly internal actors such as elected politicians and officials, bureaucrats, and political parties, are constrained by their preferences, goals and capabilities. This group is driven, and can be constrained, by their preferences, which can be individual, or result from advocacy groups or their electorate. In the same way, policy transfer/diffusion can be influenced by political goals, such as re-election, or policy goals, namely the desire to achieve a particular result (Graham, Shipan and Volden 2012). Similarly, go-between actors such as policy experts, policy entrepreneurs and consultants have their own motives for advocating specific sorts of policies, creating a national or international policy network, and promoting best policy practice (Dolowitz and Marsh 1996, 2000).

These constraints and possibilities are linked to the four main mechanisms in policy transfer/diffusion, namely learning, competition, coercion and mimicry (Marsh and Sharman 2010). The first mechanism, learning, is related to voluntary transfers/diffusion when actors choose to transfer policies due to a perceived interest. Competition, an indirect form of coercive transfer/diffusion, applies when governments adopt similar policies to attract investments. Coercion, understood as direct coercion, occurs when a policy or set of policies is imposed by a country or an international or supranational organisation, and must be implemented. Mimicry, also called emulation or socialisation, occurs when policies are adopted for normative reasons, notably their social value, rather than their technical merits, which is also an indirect coercive form of transfer/diffusion (Dolowitz and Marsh 1996, 2000; Marsh and Sharman 2010; Graham, Shipan and Volden 2012). 
Understanding these mechanisms helps one to understand what can be transferred or diffused. Seven different objects can be identified, namely: a) policy goals; b) policy structures; c) policy instruments; d) policy programmes; e) institutions; f) ideologies; g) ideas and attitudes; and h) negative lessons. According to the literature, these transfers can take place at the local, national and international levels of governance. However, there is no set hierarchy, with every level free to draw lessons from the others (Dolowitz and Marsh 2000). Finally, there are different degrees of policy transfer and diffusion: copying, when the entire policy is transferred or diffused without any amendments; emulation, ${ }^{7}$ when the idea behind a policy and not the policy itself is involved; combination, when different policies are combined; and inspiration, when policies from elsewhere leads to policy changes, but with different outcomes ${ }^{8}$ (Dolowitz and Marsh 2000). Against this background, we will now examine the UTSC.

\section{The Mercocities UTSC: a general overview}

Mercocities thematic units deal with specific themes within the network. More specifically, they are responsible for formulating and proposing public policies and indicators; promoting research and discussions; and fostering missions aimed at spreading knowledge of successful policy experiences, thus enabling their reproduction (Mercociudades 2016a). Established in 2004, the UTSC is tasked with addressing security themes from an integrated perspective which respects democracy and human rights, and dealing with issues related to the development of safer societies (Mercociudades 2016b). Since then, the UTSC has been co-ordinated by 12 cities, mainly Argentine and Brazilian, in five periods. Gravataí (BR) and Canoas (BR) have co-ordinated two periods each, and Pergamino (AR) has co-ordinated four. The periods and co-ordinating cities are listed in Table 1.

Table 1: Co-ordination of the UTSC, 2004-2016

\begin{tabular}{|c|c|c|c|}
\hline Summit & Coordinator & Deputy Coordinators & Period \\
\hline$x$ & Assunción (PY) & Guarulhos (BR) & $2004-2005$ \\
\hline XI & Diadema (BR) & Buenos Aires (AR), Santa Maria (BR) & $2005-2006$ \\
\hline XII & Gravataí (BR) & - & $2006-2007$ \\
\hline XIII & $\begin{array}{l}\text { Gravataí (BR) Valparaíso } \\
\text { (CH) }\end{array}$ & Barquisimeto (VE), Montevideo (UY), Esteio (BR) & $2008-2009$ \\
\hline XIV & Canoas (BR) & Maldonado (UY), Quilmes (AR) & $2009-2010$ \\
\hline$X V$ & Canoas (BR) & Pergamino (AR), Quilmes (AR) & $2010-2011$ \\
\hline XVI & Pergamino (AR) & Jesús María (AR), São Bernardo (BR), Assunción (PY) & $2011-2012$ \\
\hline XVII & Pergamino (AR) & São Bernardo (BR), Jesús María (AR), Canoas (BR) & $2012-2013$ \\
\hline XVIII & Pergamino (AR) & Porto Alegre (BR), Jesus María (AR) & $2013-2014$ \\
\hline XIX & Pergamino (AR) & Tandil (AR), Morón (AR), Canoas (BR) & $2014-2015$ \\
\hline$X X$ & Tandil (AR) & Lo Prado (AR), Porto Alegre (BR) & $2015-2016$ \\
\hline
\end{tabular}

Source: Compiled by the authors, based on information drawn from the Mercociudades archive. 
In 2005, in order to better evaluate the work of the thematic units, Mercocities, through its Permanent Technical Secretariat (Secretaria Técnica Permanente da Mercocidades, or STPM), created a ranking and assessment methodology. It analyses the existence and quality of work plans, activities, products and participation in every thematic unit. Each item is ranked from 0 to 2, namely: (0) nothing has been done; (1) minimal development; (2) good development. The final ranking is calculated from the following scores: Paralyzed (0-2 points); Minimal Activity (3-4 points); Active (5-6 points); Proactive (7-8 points) (STPM 2005). The UTSC ranking from 2005 until 2015 is reflected in Figure 2.

Table 2: Citizen Security Thematic Unit Evaluation (2005-2015)

\begin{tabular}{lllllll}
\hline Period & Work Plan & Activities & Products & Participation & Total & Classification/Rank \\
\hline $2005-2006$ & 0 & 0 & 0 & 0 & 0 & Paralysed \\
$2006-2007$ & 1 & 1 & 0 & 1 & 3 & Minimal Activity \\
$2008-20099$ & - & - & - & - & - & - \\
$2009-2010$ & 2 & 2 & 0 & 2 & 6 & Active \\
$2010-2011$ & 1 & 2 & 1 & 2 & 6 & Active \\
$2011-2012$ & 2 & 2 & 2 & 2 & 8 & Proactive \\
$2012-2013$ & 2 & 2 & 2 & 2 & 8 & Proactive \\
$2013-2014$ & 2 & 2 & 1 & 1 & 6 & Active \\
$2014-2015$ & 2 & 1 & 1 & 2 & 6 & Active \\
\hline
\end{tabular}

Source: Compiled by the authors, based on STPM reports in the Mercociudades archive.

It shows that, from 2005 to 2009, the UTSC did almost nothing. However, between 2009 and 2015 it became very active. According to Mercocities' own assessment methodology (STPM 2005), it developed work plans and policy programmes; held workshops, seminars and other meetings; published e-bulletins, reports and databases; and secured the participation of six cities in three different Mercosul member countries.

This makes it possible to analyse the UTSC's activities between 2010 and $2015 .{ }^{10}$ We will now describe and analyse the topics the UTSC focuses on and the projects and experiences it has promoted, detailing its projects and main courses of action. The data is mainly drawn from the work plans and management reports published by Mercocities and its STPM, but are also based on UTSC publications, which provide an important picture of its activities.

In the first period, from 2010 to 2011, the work plans envisage strengthening the public security local managers network, and interaction between the UTSC and other governmental and international agencies on security themes, such as the UN Office on Drugs and Crime (UNODC) and the Brazilian Public Security Forum (FBSP), ${ }^{11}$ as well as other branches of MERCOSUL. They also promote the improved management of criminal data; the establishment of public security observatories; and the introduction of stable and permanent financing structures for the security areas (UTSC 2010).

According to the management report, released in 2011, the UTSC interacted and exchanged experiences with other Mercocities thematic units, particularly the Youth Unit, 
the Municipality and Gender Unit, and the Human Rights Commission, but also with the FBSP, and participated in debates in different fora, including academic conferences. ${ }^{12}$ Two UTSC meetings were held during that period, and technical visits were made (STPM 2011).

In the second period, from 2011 to 2012, the work plan reflects a threefold axis, namely domestic violence, under-age reinsertion, and citizen security and human rights. It also records the experiences of Pergamino (AR), the UTSC co-ordinator for that period, and the relevance of each subject. In the case of domestic violence, Pergamino participated in a project co-funded by the European Commission, which, according to the work plan, gave the city access to good practices in public security policies. As in the previous period, the UTSC stated its intention to promote articulation among governmental agencies at different levels, and promote meetings for sharing experiences. The report also includes accounts of experiences and good practices in the cities participating in the UTSC (UTSC 2011).

According to the STPM assessment for 2012, 'capacity-building courses for combating family violence and children abuse' were held by the Ministry of Justice in the Province of Buenos Aires; and a meeting about and training for 'integrated public policies for citizen security and violence prevention' were held and presented in São Bernardo do Campo (BR). However, the main activity in that period is recorded in a publication released by UTSC in 2012, entitled Security as a Collective Construction (STPM 2012). It includes ten articles by different cities participating in the UTSC, outlining good practices and the views held by each city on matters of public and citizen security (UTSC 2012a).

The UTSC work plan for 2012-2013 presents a new fourfold work axis, based on road safety, comprehensive policies for violence prevention, and concept standardisation. Objectives include an intention to generate and deepen relations with other governments and non-government entities in order to create synergy; promote the treatment of road safety matters as a priority element of citizen security; and generate discussions, reflections and capacity-building for local agents and public servants (UTSC 2012b).

The STPM reports also show that two meetings were held, the first in Porto Alegre (BR), and the second in Pergamino (AR). A third meeting was cancelled due to a lack of participation. The meetings were attended by representatives of civil society organisations (CSOs) and government institutions, including the Buenos Aires Province Northeaster University, the Pergamino Road Safety Agency, Estrellas Amarillas, and others. In this period, the UTSC held its 'First International Congress and Third Local Congress on Road Safety' in Pergamino. The UTSC participated in the 2013 Thematic Social Forum forming part of the World Social Forum, and the report also noted the preparation of a second publication on citizen security (STPM 2013).

In the period from 2013 to $2014,{ }^{13}$ the UTSC adopted a new threefold work axis, with road safety, culture for education, and urban violence as the main themes. It retained many of its previous objectives, but added the promotion of social and citizen participation (UTSC 2014b; STPM 2014). One highlight was a UTSC meeting in Jesús Maria (AR), where experiences related to the axis themes were shared and workshops to promote reflections and insights among the participating cities were held. Of the three meet- 
ings planned for that period, only two were held, with the third being cancelled due to a lack of participation. Articulations resulted in a joint event with the Urban Development Thematic Unit, held in Zárate (AR).

The main result in this period was a second edition of Security as a Collective Construction (STPM 2014). It again contained ten articles, five of which centred on road safety, and presenting local experiences and good practices from associated cities (UTSC 2014a).

In the last period analysed, from 2014 to 2015, the main objectives were the same as previously, but the work axis changed to road safety, urban violence, and the de-penalisation of drug consumption (UTSC 2014b). A workshop on 'Road insecurity: policies from the local government' held in Tandil (AR) produced a document to be presented to the Mercocities Council on road safety policies. Another workshop on 'Democratic Security and Human Rights: innovative experiences from local governments', held in Morón (AR), represented an articulation between UTSC and the Mercocities Human Rights Commission (STPM 2015). A third edition of Security as a Collective Construction was published in 2015, with only two articles discussing road safety and proposals for the UTSC (UTSC 2015).

This summary of UTSC activities covers some of its main objectives and work axes during its most active period. However, it also serves as an inventory of what happened at the UTSC during the whole period under evaluation. In the next section, we analyse the relevance of the unit as a citizen security forum, and seek to gain an understanding of how the unit developed its activities through a policy transfer approach.

\section{Citizen security in Mercocities: a brief analysis of the UTSC}

The UTSC's work plans provide a useful picture of its interests, proposals and activities in the period 2010 to 2015. They reveal an intent to foster citizen security as a relevant theme within Mercocities as well as Mercosul, and within each participating country, especially via linkages with ministries dealing with security themes, and partnerships and agreements with national and international CSOs. The work plans also reflect the main thematic areas on which the co-ordinator city intended UTSC to focus during a given period. This is particularly evident in Pergamino's co-ordinating period in 2011-2012. The work plans improved steadily during each period.

However, they essentially contain sets of intentions and planned activities. In order to assess their effective realisation, it is necessary to examine the STPM reports, which contain brief summaries of each unit's activities. ${ }^{14}$ The STPM reports from 2010 to 2015 show that most of the meetings, activities and publications planned by the UTSC were actualised. Nevertheless, due to a lack of participation by associated cities, some meetings were cancelled, some planned activities were undermined, and publications failed to attract contributions. The reports largely reflect a positive evaluation of the UTSC, but identify a lack of participation as its main problem (STPM 2011, 2012, 2013, 2014, 2015).

The UTSC's activities in the period 2010-2015 resulted in a stronger focus on the exchange of experiences and good practices in respect of public security policies, with different participating cities making presentations at every meeting. Those experiences 
were also presented in the three UTSC publications entitled Security as a Collective Construction.

The 2012 edition contains articles around the general theme of citizen security, addressing the involvement of cities in citizen security, and proposes 'security as collective construction' as a motto to be adopted and practised. The 2014 edition has traffic safety as its general theme, and contains expert analysis on this topic. The 2015 edition is in an e-bulletin format and contains only two articles, addressing the same themes. However, it also contains a proposal by UTSC member cities to the Mercocities authorities about road safety policies, such as educational programmes, public transport usage promotion, urban mobility, and infrastructure mapping, all of which is linked to UTSC' view of road safety as an integral part of citizen security (UTSC 2012a, 2014a, 2015).

Using our chosen method, we can now attempt to identify the actors, mechanisms, and issues transferred by the UTSC. The first step is to identify the actors involved in UTSC activities, and consider how they should be categorised.

The structure of the Mercocities network and its thematic units contains the first indication of who the main actors are, which is confirmed by the UTSC's work plans and the STPM reports (also see Mercociudades 2016a). In cities networks, the main actors are local governments, their elected leaders and elected and unelected officials, particularly those working in secretariats and structures related to citizen security. All of them can be understood as internal actors in public policy transfer/diffusion processes (Dolowitz and Marsh 2000; Graham, Shipan and Volden 2012).

Decisions to join the Mercocities network and the UTSC are often linked to the willingness of cities to engage in policy transfer and diffusion. The literature shows that those actors primarily act from their own preferences, seeking to achieve their own goals, and within their own capabilities (Graham, Shipan and Volden 2012). In this case, the very fact of participating in a specific thematic unit may signify that a given city has policy goals in the area in question. However, effective participation is a major challenge, due to meetings being cancelled as well as a lack of participation. Internal constraints have also played a role in undermining the participation of cities in UTSC activities.

From this, it is possible to deduce which mechanisms are involved in UTSC policy transfer and diffusion, such as learning and mimicry, which means that the process occurs from a voluntary and an indirectly coercive point of view (Dolowitz and Marsh 1996; 2000; Marsh and Sharman 2010; Graham, Shipan and Volden 2012). Participation in the UTSC is voluntary, as is the process of discussing and presenting experiences and good practices in respect of citizen security public policies. This means that every participating city can choose whether to pay attention to these experiences, and learn from them or not. However, considering that almost every work plan seeks to promote citizen security within the Mercocities network, and within each participating country, it could also be argued that a process of mimicry could occur, since the experiences and policies presented could be transferred or diffused via its normative or symbolic value. This is evident from the fact that the UTSC produced a document to be presented to the Mercocities Council with suggestions for a joint road safety policy. 
As regards the issue of what is diffused via the UTSC, it is possible to argue that the process involves policy goals, ideologies, ideas and attitudes, particularly through emulation (Dolowitz and Marsh 2000). The meetings held by the UTSC fostered discussions about citizen security policies, based on presentations of experiences and good practices, with the UTSC's three publications being an important outlet. Those publications not only promote citizen security as a theme, but also present some policy experiences, which may generate interest and effective transfers. The publications stress that citizen security as a collective construction could be an important motto, which could be adopted by each participating city. However, given the diversity of actors and their specific domestic, economic and political interests, those experiences and practices cannot simply be replicated, but need to be adapted to particular contexts.

The work plans and STPM reports do not provide enough material for an accurate analysis. However, it is possible to verify from those documents that ideologies, ideas and attitudes were transferred and diffused by promoting citizen security as a relevant theme in the Mercocities network, by recording experiences and good practices, establishing linkages with civil society and other levels of government, and fostering a comprehensive conception of citizen security in local policy. The UTSC placed the theme of citizen security on the Mercocities agenda, effectively producing an environment of debate and exchange about citizen security policies within the network.

This shows that the policy transfer/diffusion approach helps to advance an understanding of how the UTSC worked during the selected period, and provides some insights into the process. It not only provides an overview of the UTSC and its activities, but also presents new possibilities for analysing international cities networks from a public policy perspective.

\section{Conclusions}

Cities have gained a new political role, fostered by the growing prominence of a new and complex international urban agenda. Global cities in particular have experienced growing problems surrounding the provision of public services.

City paradiplomacy has become an increasingly important vehicle for horizontal public policy exchanges among local governments. In this sense, city networks have played an important role due to their ability to record and diffuse experiences and good practices that could be applied in similar local contexts elsewhere, even in other countries. The Mercocities network is one of the most active and influential networks in Latin America, and has contributed to horizontal policy exchanges and transfers in many areas.

As regards citizen security, Mercocities created the UTSC in 2004, and this theme has formed part of the debate among the various participating cities ever since. Evaluations by the network itself shows that the UTSC has been quite active, which means it has developed sustainable activities.

From a policy transfer and policy diffusion point of view, is clear that the UTSC has become an important forum for dialogues, public policy exchanges, and the diffusion of good practices. The actors involved in these processes chose to join the unit in pursuit 
of their policy goals, including creating safer local societies, and achieving their political goals, such as being recognised as models of innovative citizen security policies. Those goals can be identified by analysing the UTSC work plans, particularly from 2009 onwards, when Canoas (BR), Pergamino (AR) and Tandil (AR) presented their experiences, practices and projects, justifying their selections as UTSC co-ordinators by demonstrating their local policies for achieving citizen security.

The other member cities of the UTSC, which have not functioned as co-ordinators, also have particular goals and motivations. Those cities have sought new information about experiences and practices within the UTSC in order to improve their own citizen security policies, which could be understood as learning from the UTSC dialogues and experiences as well as from the co-ordinators. From those practices, dialogues and learning, a core set of values, including democracy, human rights, and citizen participation, have become an internal rule of the UTSC. This rule is present in the UTSC's main objectives as well as every work plan adopted by associated cities, and constitutes a kind of barrier for those cities that do not share this set of core values.

Thus, is possible to argue that UTSC transfers and diffusions involve policy goals, like crime reduction and citizen participation, and promote a set of ideologies, ideas and attitudes. As the UTSC members are diverse, with different political and economic characteristics, they cannot simply replicate the policies of others; instead, they have to adapt those policies to their particular contexts and needs. However, due to the lack of a common funding facility, associated cities have to rely on their own financial resources to implement policies on citizen security.

In fact, a lack of funding is the UTSC's main problem, as the implementation of citizen security policies depends on current city budgets. As noted previously, in the period under review, some activities had to be cancelled due to a lack of participation, largely due to a lack of financial resources, a situation that jeopardizes the UTSC, and limits its role of promoting and fostering common citizen security policy projects.

However, despite these difficulties, the UTSC may be regarded as an important forum on citizen security within Mercocities, and also for Mercosul. It has promoted its core values, and involved interested cities. Its activities also show that different policies, related to the work axes during each co-ordinating period, were actively promoted, and transferred and diffused to some extent within the UTSC. Given that the UTSC has existed for only 12 years, it is possible to assert that its agenda has impacted on the citizen security policies of at least some Mercocities members, through a collective network of paradiplomacy.

\section{Notes}

1 Newman (2010) presents two more approaches to human security. The first is related to non-traditional security threats, such as HIV/AIDS and human trafficking, stressing their main objective, namely to influence public policy. The other bridges the broad and narrow formulations, thereby including human security in security studies, and focusing on the causes of insecurity.

2 Mercocities is a regional city network established in 1995, just after the establishment of Mercosur. Mercocities became an important and dynamic cities network inside Mercosur, and a vehicle for a more active role for cities in the regional integration process. 
The Organisation for the Improvement of Higher Education Personnel (Coordenação de Aperfeiçoamento de Pessoal de Nível Superior, or CAPES) is a Brazilian federal agency forming part of the Ministry of Education, tasked with approving and evaluating Brazilian graduate programmes as well as promoting graduate activities through grants. The CAPES/Thesis Database is a well-developed thesis and dissertations database maintained by CAPES since the 1980s. CAPES rules require all graduate programmes to include their approved theses and dissertations in the database.

4 The National Association of Social Sciences Graduate Studies and Research (Associação Nacional de PósGraduação e Pesquisa em Ciências Sociais, or ANPOCS) is the main non-government entity dealing with social and human sciences graduate research in Brazil.

5 Brazilian Association of Political Science (Associação Brasileira de Ciência Política, or ABCP).

6 The Brazilian Centre of Analysis and Planning (Centro Brasileiro de Análise e Planejamento, or CEBRAP) is an autonomous research institute founded in 1969 by scholars with progressive affiliations (the former Brazilian president Fernando Henrique Cardoso played an important role), many of them threatened by the military regime. It has received Ford Foundation funding. It gathers researchers from several universities, but is strongly influenced by the Social Sciences at University of São Paulo (USP).

$7 \quad$ Note that emulation is also characterised as a type of mimicry (Marsh and Sharman 2010).

8 These degrees are linked to the policy transfer literature (Dolowitz and Marsh 1996, 2000) and could be understood as a part of the mechanisms also presented by the policy diffusion literature (Marsh and Sharman 2010; Graham, Shipan and Volden 2012). For example, copying could be a part of learning, and emulation a part of mimicry.

9 According to the STPM reports for 2008 and 2009, it was not possible to develop an assessment and ranking of the Thematic Units due a lack of information (STPM 2009).

10 The period for the analysis is based on Figure 2, Citizen Security Thematic Unit Evaluation (2005-2015), which shows that the Thematic Unit only worked continuously from 2010 to 2015.

11 The Brazilian Forum for Public Security (Fórum Brasileiro de Segurança Pública, or FBSP) comprises a group of experts and activists in the areas of public security, citizen security, and law and order who seek to develop research and training and promote advocacy on public security issues, mainly with a human rights approach. It was established in 2006, with the esupport of the Ford Foundation, Open Society Foundation, and Thiker Foundation. It publishes a National Public Security Annual Report, among many other publications.

12 The report presents the Fifth Meeting of the FBSP, the Fourth IDB Clinic-Citizen Security Forum, the XXVIII International Congress of the Latin American Sociology Association, XV Meeting of the Brazilian Sociology Association and the International Symposium on 'BRICS: Brazil as rising power'.

13 The work plan for this period is not available on the Mercocities website, so the work plan for the period 2014-2015, which contains information about 2013-2014, is used as the main source for this summary.

14 These briefings are only available in the reports from 2010 onwards.

\section{References}

Aldecoa, Francisco and Michael Keating. 1999. Paradiplomacy in Action: The Foreign Relations of Subnational Governments. New York: Routledge.

Aguirre, Iñaki. 1999. 'Making sense of paradiplomacy? An intertextual enquiry about a concept in search of a definition'. In Francisco Aldecoa and Michael Keating (eds), Paradiplomacy in Action: The Foreign Relations of Subnational Governments. London and Portland: Frank Cass, pp. 185-209. Anderson, George. 2008. Federalism: An Introduction. Oxford University Press.

Borja, Jordi and Manuel Castells. 1997. Local and the Global: Management of Cities in the Information Age. London: Earthscan. 
Brazilian Center for Analysis and Planning (CEBRAP). 2016. International Seminar on Policy Diffusion. At https://policydiffusion.com/ [Accessed on 5 September 2016].

Castells, Manuel and Jordi Borja. 1996. 'As cidades como atores políticos'. Novos Estudos CEBRAP, São Paulo, 45: 153-166.

Citizen Security Thematic Unit of Mercocities (UTSC). 2010. Plano de Trabalho: 2010-2011. At http://www.mercociudades.org/sites/portal.mercociudades.net/files/archivos/documentos/ut/ Plan_UTSC_2011.pdf [Accessed on 12 August 2016].

. 2011. Plan de Trabajo: 2011-2012. At http://www.mercociudades.org/sites/portal.mercociudades.net/files/archivos/documentos/ut/Plan_Trabajo_UTSC_2012.pdf [Accessed on 12 August 2016].

. 2012a. La Seguridad Ciudadana como una Construcción Colectiva. At http://www.mercociudades.org/sites/portal.mercociudades.net/files/archivos/documentos/Publicaciones/Publicacion_ Seguridad_Ciudadana.pdf [Accessed on 12 August 2016].

. 2012b. Plan de Trabajo: 2012-2013. At http://www.mercociudades.org/sites/portal.mercociudades.net/files/archivos/documentos/Unidades_Tematicas/UTSC_2013.pdf [Accessed on 12 August 2016].

. 2014a. La Seguridad Ciudadana como una Construcción Colectiva. At http://www.mercociudades.org/sites/portal.mercociudades.net/files/archivos/documentos/Unidades_Tematicas/Publicacion_Seguridad_Ciudadana_2014.pdf [Accessed on 12 August 2016].

. 2014b. Plan de Trabajo: 2014-2015. At http://www.mercociudades.org/sites/portal.mercociudades.net/files/archivos/documentos/Unidades_Tematicas/Plan_UTSC_2015.pdf [Accessed on 12 August 2016].

. 2015. La Seguridad Ciudadana como una Construcción Colectiva. At http://www.mercociudades.org/sites/portal.mercociudades.net/files/archivos/documentos/Unidades_Tematicas/Boletin_UTSC_2015_oct.pdf [Accessed on 12 August 2016].

Cornago, Noé. 1999. 'Diplomacy and paradiplomacy in the redefinition of international security: dimensions of conflict and co-operation'. In Francisco Aldecoa and Michael Keating (eds), Paradiplomacy in Action: The Foreign Relations of Subnational Governments. London and Portland: Frank Cass, pp. 40-57.

Dolowitz, David and David Marsh. 1996. 'Who learns what from whom: a review of the policy transfer literature.' Political Studies, Volume XLIV: 333-357.

. 2000. 'Learning from abroad: the role of policy transfer in contemporary policy making. Governance: An International Journal of Policy and Administration, 13(1): 5-23.

Duchacek, Ivo. 1986. The Territorial Dimension of Politics: Within, Among and Across Nations. Boulder and London: Westview Press.

. 1990. 'Perforated sovereignties: toward a typology of new actors in international relations'. In: Hans Michelmann and Panayotis Soldatos (eds), Federalism and International Relations: the Role of Subnational Units. Oxford: Clarendon Press.

Faria, Carlos, Pimenta de Aurélio, Denilson Bandeira Coelho and Sidney Jard da Silva. 2016 'Introdução' In: Carlos Aurélio Pimenta de Faria, Denilson Bandeira Coelho and Sidney Jard da Silva, Difusão de Políticas Públicas. São Bernardo do Campo: Editora UFABC, pp. 11-31.

Fukuda-Parr, Sakiko and Carol Messineo. 2012. 'Human security: A critical review of literature'. CRPD Working Paper No. 11. Leuven: Catholic University Leuven. 
Gilardi, Fabrizio. 2012. ‘Transnational diffusion: norms, ideas, and practices'. In: Thomas Risse and Beth Simmons (eds), Handbook of International Relations. Thousand Oaks: Sage Publications, pp. 453-77.

Graham, Erin, Charles Shipan and Craig Volden. 2012. 'The diffusion of policy diffusion research in political science. British Journal of Political Science, 43(3): 1-29.

Happaerts, Sander, Karoline Van den Brande and Hans Bruyninckx. 2011. 'Subnational governments in transnational networks for sustainable development'. International Environment Agreements 11.

Hocking, Brian, 1993. Localizing Foreign Policy: Non-central Governments and Multilayered Diplomacy. New York: St. Martin Press.

2004. 'Regionalismo: uma perspectiva das relações internacionais'. In: Tullo Vigevani, Luiz

Eduardo Wanderley, Maria Inês Barreto and Marcelo Passini Mariano (eds), A Dimensão Subnacional e as Relações Internacionais. São Paulo: Educ/Unesp/EdUSC, pp. 77-107.

Inter-American Commission on Human Rights (IACHR). 2009. Report on Citizen Security and Human Rights. Washington. At http://www.cidh.org/countryrep/Seguridad.eng/CitizenSecurity. II.htm\#_ftn3 [Accessed on 26 August 2016]

Inter-American Development Bank (IDB). 2017. The Cost of Crime and Violence: New Evidences and Insights in Latin America and the Caribbean. Washington. At https://publications.iadb.org/ bitstream/handle/11319/8133/The-Costs-of-Crime-and-Violence-New-Evidence-and-Insights-inLatin-America-and-the-Caribbean.pdf?sequence=7 [Accessed on 18 february 2017]

Kuznetsov, Alexander S. 2015. Theory and Practice of Paradiplomacy: Subnational Governments in International Affairs. New York: Routledge.

Lecours, Andre. 2008. Political Issues of Paradiplomacy: Lessons from the Developed World. The Hague: Netherlands Institute of International Relations.

Marin, Pedro de Lima. 2011 'Mercosul e a disseminação international de políticas públicas'. Cadernos de Gestão Pública e Cidadania, 16: 7-22

Marsh, David and Jason Sharman. 2010. 'Policy diffusion and policy transfer.' In: Mark Evans (ed), New Directions in the Study of Policy Transfer. New York: Routledge, pp. 32-51.

Mello, Simone Cardoso de Assumpção. 2013. Cooperação Internacional e Transferência de Políticas Públicas no Campo da Comunicação Social: O Papel da UNESCO na Reforma da Radiodifusão do Brasil. Master's Dissertation, University of Grande Rio.

Mercociudades. 2016a. Estatuto y Reglamento de Mercociudades. At http://www.mercociudades.org/ node/2273 [Accessed on 12 August 2016].

. 2016b. Seguridad Ciudadana. At http://www.mercociudades.org/UTSC [Accessed on 12 August 2016].

2016c. Documentos y Archivos. At http://www.mercociudades.org/node/2100 [Accessed on 12 August 2016].

2016d. Documentos y Archivos: Seguridad Ciudadana. At http://www.mercociudades.org/ node/2141 [Accessed on 12 August 2016].

Michelmann, Hans (ed). 2009. Foreign Relations in Federal Countries. Montreal: McGill-Queen's University Press.

Milani, Carlos Roberto Sanchez and Roberta Nunes Lopes. 2014. 'Cooperação Sul-Sul e policy transfer em saúde pública: análise das relações Brasil e Moçambique entre 2003 e 2012'. Carta Internacional, 9(1): 59-78. 
Newman, Edward. 2010. 'Critical human security studies'. Review of International Studies, 36: 77-94. Oliveira, Osmany Porto de. 2013. Embaixadores da Participação: a Difusão Internacional do Orçamento Participativo a partir do Brasil. PhD Thesis. University of São Paulo.

Permanent Technical Secretariat of Mercocities (STPM). 2005. Informe de la Secretaría Técnica Permanente de Mercociudades: 2005. At http://www.mercociudades.org/sites/portal.mercociudades. net/files/archivos/documentos/InformesGestion/STPM/informeSTPM-2005.pdf [Accessed on 12 August 2016].

. 2009. Informe de la Secretaría Técnica Permanente de Mercociudades: 2008-2009. At http:// www.mercociudades.org/sites/portal.mercociudades.net/files/archivos/documentos/InformesGestion/STPM/informeSTPM_2008_09.pdf [Accessed on 12 August 2016].

. 2011. Informe de la Secretaría Técnica Permanente de Mercociudades: 2010-2011. At http:// www.mercociudades.org/sites/portal.mercociudades.net/files/archivos/documentos/Publicaciones/Informe_STPM_SE_2010_11_Espanol.pdf [Accessed on 12 August 2016].

. 2012. Informe de la Secretaría Técnica Permanente de Mercociudades: 2011-2012. At http:// www.mercociudades.org/sites/portal.mercociudades.net/files/archivos/documentos/Publicaciones/Informe_SE_STPM_2012_esp.pdf [Accessed on 12 August 2016].

. 2013. Informe de la Secretaría Técnica Permanente de Mercociudades: 2012-2013. At http:// www.mercociudades.org/sites/portal.mercociudades.net/files/archivos/documentos/Publicaciones/InformeAnualEsp_2012-2013.pdf [Accessed on 12 August 2016].

. 2014. Informe de la Secretaría Técnica Permanente de Mercociudades: 2013-2014. At http:// www.mercociudades.org/sites/portal.mercociudades.net/files/archivos/documentos/Publicaciones/InformeAnualEsp_2013-2014.pdf [Accessed on 12 August 2016].

. 2015. Informe da Secretaria Executiva e da Secretaria Técnica Permanente de Mercociudades: 2014-2015. At http://www.mercociudades.org/sites/portal.mercociudades.net/files/archivos/documentos/Publicaciones/informe_port\%202014_2015.pdf [Accessed on 12 August 2016].

Rodrigues, Gilberto Marcos Antonio. 2008. 'Relações internacionais federativas no Brasil'. Dados, 1(4): 1015-1034.

Rodrigues, Gilberto Marcos Antonio, Marcos Xavier and Wagner de Melo Romão (eds). 2009. Cidades em Relações Internacionais: Análises e Experiências Brasileiras. São Paulo: Desatino.

Rodrigues, Gilberto Marcos Antonio and Thiago Mattioli. 2016. 'Políticas públicas e redes internacionais de cidades: o Programa URB-AL’. In: Cuadernillos FUNPADEM. San José, Costa Rica: Fundación del Servicio Exterior para a Paz y la Democracia, Vol. 4, pp. 61-75.

Sassen. Saskia, 2001. The Global City. New York: Princeton University Press.

Shipan, Charles R and Craig Volden. 2012. 'Policy diffusion: seven lessons for scholars and practitioners'. Public Administration Review, 72: 788-796.

Soldatos, Panayotis. 1990. 'An explanatory framework for the study of federated states as foreign policy actors'. In: Hans Michelmann and Panayotis Soldatos (eds), Federalism and International Relations: the Role of Subnational Units. Oxford: Clarendon Press, pp. 34-53.

Tavares, Rodrigo. 2016. Paradiplomacy. Oxford University Press.

United Nations Development Programme (UNDP). 1994. Human Development Report 1994. At http://hdr.undp.org/sites/default/files/reports/255/hdr_1994_en_complete_nostats.pdf [Acessed on 12 august 2016]. 
United Nations Trust Fund for Human Security (UNTFHS). 2009. Human Security in Theory and Practice: An Overview of the Human Security Concept and the United Nations Trust Fund for Human Security. At http://www.un.org/humansecurity/sites/www.un.org.humansecurity/files/human_security_in_theory_and_practice_english.pdf [Accessed on 12 august 2016].

Vigevani, Tullo Luiz. Eduardo Wanderley, Maria Inês Barreto and Marcelo Passini Mariano (eds). 2004. A Dimensão Subnacional e as Relações Internacionais. São Paulo: Educ/Unesp/EdUSC.

Vital, Graziela C. 2016. A Institucionalização das Relações Externas Subnacionais: um Estudo Comparado das Cidades de São Paulo e Toronto. PhD thesis, University of São Paulo.

\section{About the authors}

Gilberto Marcos Antonio Rodrigues is Adjunct Professor (tenured) of International Relations at the Federal University of $\mathrm{ABC}$ (UFABC), and a researcher at the National Council for Scientific and Technological Development (CNPq/MCTIC), Brazil. In 2017, he was a Research Fellow of the Centre for Latin American and Latino Studies (CLALS) of the American University, USA, and in 2010, a Fulbright Visiting Scholar at the Centre for Civil and Human Rights of the University of Notre Dame, USA. He has published extensively on international organisations, human rights and federalism. His latest publication is a chapter on 'Concurrent Power and Local Interest in Brazil's Federalism' in a book edited by Brill-Nijhoff (2017).

Thiago Mattioli is a PhD candidate in Human and Social Sciences at the Federal University of $\mathrm{ABC}$ (UFABC), Brazil. He holds an MA in Human and Social Sciences from the same university, and a BA in International Relations from the Santo Andre Foundation University Centre, Brazil. His doctoral research deals with the application of the notions of policy transfer and policy diffusion to decentralised international co-operation via international city networks. His research interests include decentralised co-operation for development, and paradiplomacy. He has twice come second in the UFABC Graduate Student Human and Social Sciences competition. He currently holds a scholarship from the same institution.

\section{Paradiplomacia, Políticas de Segurança e Redes de Cidades: o Caso da Unidade Temática de Segurança Cidadã das Mercocidades}

\footnotetext{
Resumo: Através do fenômeno conhecido como paradiplomacia, as cidades estão desempenhando um papel cada vez mais importante nas relações internacionais. Por meio da paradiplomacia, as cidades estão cooperando internacionalmente com outras cidades, e as redes de cidades tornaram-se espaços importantes para
} 
o compartilhamento de experiências e de melhores práticas em políticas públicas locais. Além disso, a política de segurança é uma parte cada vez mais importante da elaboração de políticas locais. $\mathrm{Na}$ América Latina, o conceito de segurança cidadã, baseado em uma abordagem democrática e de direitos humanos, foi desenvolvido em resposta ao legado dos regimes autoritários que vigoraram dos anos de 1960 à decada de 1980. Este artigo examina como as políticas de segurança foram disseminadas, discutidas e transferidas através das Mercocidades, a principal rede de cidades da América do Sul.

Palavras-chave: Paradiplomacia; Cooperação Internacional Descentralizada; Mercocidades; Políticas de Segurança; Secirança Cidadã; Transferência de Políticas; Difusão de Políticas.

Received on 1 September 2016, and approved for publication on 8 May 2017.

\section{(cc) BY-NC} https://creativecommons.org/licenses/by-nc/4.0/ 